\title{
Plasma ion levels of freshwater and marine/estuarine teleosts from Southern Brazil
}

\author{
Alexssandro Geferson Becker ${ }^{1}$, Jamile Fabbrin Gonçalves ${ }^{1}$, Jaderson dos Anjos Toledo ${ }^{2}$, \\ Marcelo D. M. Burns 3 , Luciano de Oliveira Garcia ${ }^{3}$, João Paes Vieira ${ }^{3}$ and \\ Bernardo Baldisserotto ${ }^{1}$
}

\begin{abstract}
The purpose of this study was to investigate $\mathrm{Na}^{+}, \mathrm{Cl}^{-}, \mathrm{K}^{+}, \mathrm{Ca}^{2+}$, and $\mathrm{Mg}^{2+}$ levels in the plasma of freshwater and marine/ estuarine teleosts collected at different salinities (0 to 34) from the estuarine and freshwater portions of the São Gonçalo channel in Southern Brazil. Any relationship between plasma ion levels and salinity and the capacity of ionic regulation of teleosts found at three or more different salinities (Genidens barbus and Micropogonias furnieri) was also investigated. Results showed no relationship between plasma ion levels and salinity when considering all species together, but the two species collected from three or more different salinities showed a significant positive relationship between plasma ion levels and salinity, indicating that G. barbus and M. furnieri have a high capacity to regulate plasma ion levels at both low and high salinities.
\end{abstract}

A proposta deste estudo foi investigar os níveis de $\mathrm{Na}^{+}, \mathrm{Cl}^{-}, \mathrm{K}^{+}, \mathrm{Ca}^{2+}$, and $\mathrm{Mg}^{2+}$ no plasma de teleósteos de água doce e marinhos/estuarinos coletados em diferentes salinidades (0 a 34) nas porções de água doce e estuarinas do Canal São Gonçalo, sul do Brasil. Uma possível relação entre os níveis iônicos plasmáticos e a salinidade também foi investigada bem como a capacidade de regulação iônica dos teleósteos coletados em três ou mais salinidades (Genidens barbus e Micropogonias furnieri). Os resultados mostraram que não houve relação entre os níveis iônicos no plasma com a salinidade quando considerando todas as espécies juntas, mas as duas espécies coletadas em três ou mais salinidades mostraram uma relação significativamente positiva entre níveis iônicos no plasma e salinidade, mostrando que G. barbus e M. furnieri apresentaram uma grande capacidade para regular os íons do plasma em baixas e altas salinidades.

Keywords: Ariidae, Estuaries, Ionoregulation, Osmoregulation, Salinity, Sciaenidae.

\section{Introduction}

The capacity to regulate plasma ion levels in conditions of changing external salinity is necessary for fish that either live in estuaries or that migrate between freshwater and seawater as part of their normal life cycle. The response to changes in salinity may need to be rapid (such as during tidal cycles or rapid movements through estuaries) or slow (such as for the seasonal or ontogenetic acquisition of salinity tolerance in anadromous fish) (McCormick, 2001). Thus, estuarine teleosts are euryhaline species and efficient osmoregulators by necessity (Prodócimo \& Freire, 2001).

In Southern Brazil, the most important estuary is the Patos Lagoon $\left(10,227 \mathrm{~km}^{2}\right)$, which is connected to the Mirim Lagoon $\left(3,750 \mathrm{~km}^{2}\right)$ by the São Gonçalo Channel. This natural channel is $75 \mathrm{~km}$ long, $200-500 \mathrm{~m}$ wide, $6 \mathrm{~m}$ deep, and is obstructed by the São Gonçalo dam to prevent salt water intrusion into the
Mirim Lagoon during the dry season (Burns et al., 2006; Da Rocha et al., 2009).

Analysis of plasma ion levels in neotropical teleosts has generally been performed in the laboratory on specimens acclimated to either freshwater (Baldisserotto \& Mimura, 1997; Borges et al., 2004; Becker et al., 2009) or seawater (Altinok et al., 1998; Prodócimo \& Freire, 2001; Sampaio \& Bianchini, 2002). The ionic regulation of two species of pufferfish (Sphoeroides testudineus and S. greeleyi) (Prodócimo \& Freire, 2001) and a flounder (Paralichthys orbignyanus) (Sampaio \& Bianchini, 2002) was also studied when fish were subjected to salinity changes in the laboratory. Only one study has analyzed the plasma ion content of fish immediately collected from their natural freshwater environments (Becker et al., 2006).

The purpose of this study was to investigate $\mathrm{Na}^{+}, \mathrm{Cl}^{-}, \mathrm{K}^{+}$, $\mathrm{Ca}^{2+}$, and $\mathrm{Mg}^{2+}$ levels in the plasma of freshwater and marine/ estuarine teleosts collected from the freshwater and estuarine

'Universidade Federal de Santa Maria, Departamento de Fisiologia e Farmacologia, 97105-900 Santa Maria, RS, Brazil. bbaldisserotto@hotmail.com

${ }^{2}$ Universidade Federal de Santa Maria, Departamento de Solos, 97105-900 Santa Maria, RS, Brazil.

${ }^{3}$ Universidade Federal do Rio Grande, Instituto de Oceanografia, 96201-900 Rio Grande, RS, Brazil. 
regions of the São Gonçalo channel in Southern Brazil from water at different salinities ( 0 to 34 ). Any relationship between plasma ion levels and salinity and the capacity of ionic regulation of teleosts found at three or more different salinities was also investigated. Therefore, this study provides a better understanding of plasma ion regulation in freshwater and marine/estuarine teleosts in the wild.

\section{Material and Methods}

During three sampling periods (February 2005, April 2006, and December 2006), fish were collected from water at different salinities from the estuarine (downstream) and freshwater (upstream) regions of the São Gonçalo channel (Table 1). Freshwater and marine/estuarine teleosts were collected using a shrimp trawl ( $10.5 \mathrm{~m}$ head rope, $0.5 \mathrm{~cm}$ bar mesh in the center, $1.3 \mathrm{~cm}$ bar mesh along the wings) deployed for $5 \mathrm{~min}$ by a wood boat with a $60 \mathrm{hp}$ engine. Samples were also taken from shallow water on both sides of the dam using a beach seine $(9 \mathrm{~m})$.

Fish were classified into four ecological guilds (see Table 1) as previously described by Garcia et al. (2003a): 1) estuarine residents - species typically residing occurring and breeding within the estuary; 2) estuarine dependents - marine- or freshwater-spawning species found in large numbers within the estuary during certain periods of their life cycle; 3) marine vagrants - typically inhabiting marine habitats and rarely occurring within the estuary; 4) freshwater vagrants - typically inhabiting freshwater habitats and rarely occurring within the estuary. The last guild was further split into first-order freshwater fish, (ecologically restricted to freshwater) and second-order freshwater fish (generally restricted to freshwater but able to survive, and occasionally occur, in saltwater) (Vieira et al., 1998).

After collection, fish were stunned with a blow to the head. Blood was collected from the caudal vein with heparinized 1$\mathrm{mL}$ syringes and refrigerated in Eppendorf tubes. Specimens were then euthanized by severing the spinal cord, weighed and measured (Table 1). All blood samples were stored on ice and transported to the Fish Physiology Laboratory/UFSM. Samples were then centrifuged at 2,000 rpm for $5 \mathrm{~min}$ to separate the plasma and were stored at $-20^{\circ} \mathrm{C}$ for subsequent analysis.
Field water salinity was measured with a handheld salinity meter, and plasma chloride concentration was measured according to Zall et al. (1956). Sodium and potassium ion concentrations were measured with a B262 flame spectrophotometer (Micronal, São Paulo, Brazil); calcium and magnesium ion concentrations were measured using a GBC 932AA atomic absorption spectrophotometer (GBC Scientific Equipment, Victoria, Australia). Standard solutions were made with analytical grade reagents (Vetec or Merck) dissolved in deionized water, and standard curves of each ion were calculated using five different concentrations. This study was approved by the Ethical and Animal Welfare Committee of the Universidade Federal de Santa Maria (process number 23081.008434/2007-85). The identification of the fishes was performed by comparisons with existing vouchers in the Laboratório de Ictiologia (FURG).

All data are expressed as the means \pm standard error of the mean (SEM). Relationships between plasma ion levels, salinity and ion regulation curves were made using the Sigma Plot 11.0 software set at a minimum significance level of $P<0.05$.

\section{Results}

Fish were categorized into the following groups: estuarine residents (one species), estuarine dependents (six species), marine vagrants (one species) and freshwater vagrants (five species) (Table 1).

Although there was no relationship between plasma ion levels and water salinity when considering all species together (Table 2), a significant relationship was observed for two species collected from water at three or more different salinities. Micropogonias furnieri and Genidens barbus exhibited a positive relationship between plasma $\mathrm{Na}^{+}, \mathrm{Cl}^{-}, \mathrm{Ca}^{2+}$, and $\mathrm{Mg}^{2+}$ levels and water salinity and a negative relationship between plasma $\mathrm{K}^{+}$levels and salinity (Fig. 1).

The ionic regulatory capacity was also verified in the two species collected from water at three or more different salinities (G. barbus and M. furnieri) (Fig. 1). Genidens barbus and $M$. furnieri hyperregulated $\mathrm{Na}^{+}$and $\mathrm{Cl}^{-}$levels to keep plasma values above the isoionic line at a salinity of 5 or below, but

Table 1. Freshwater and marine/estuarine teleosts collected from water at different salinities from the São Gonçalo channel. Specimens were classified according to ecological guild: ESR: estuarine residents; ESD: estuarine dependents (diadromous); MARV: marine vagrants and FRV: freshwater vagrants (Vieira et al., 1998; Garcia et al., 2003a). Values are presented as the means \pm SEM.

\begin{tabular}{|c|c|c|c|c|c|c|}
\hline Species & Voucher numbers & Ecological guild & Salinity & Weight (g) & Length $(\mathrm{cm})$ & $\mathrm{N}$ \\
\hline Hypostomus commersoni & FURG 88034 & FRV & 0 & $515.20 \pm 1.86$ & $37.35 \pm 1.20$ & 12 \\
\hline Micropogonias furnieri & FURG 2499 & ESD & $0 ; 5 ; 24 ; 26 ; 29 ; 34$ & $56.15 \pm 2.41$ & $12.10 \pm 1.14$ & 12 \\
\hline Parapimelodus nigribarbis & FURG 2545 & FRV & 0 & $305.15 \pm 1.26$ & $24.86 \pm 1.33$ & 12 \\
\hline Pimelodus pintado & FURG 1216 & FRV & $0 ; 5$ & $816.13 \pm 3.49$ & $30.14 \pm 1.41$ & 12 \\
\hline Rhamdia quelen & FURG 2241 & FRV & 0 & $620.10 \pm 4.51$ & $35.24 \pm 1.56$ & 12 \\
\hline Cyphocharax voga & FURG 2539 & FRV & $0 ; 5$ & $155.15 \pm 2.12$ & $28.23 \pm 1.23$ & 12 \\
\hline Genidens barbus & FURG 94018 & ESD & $5 ; 24 ; 29$ & $570.21 \pm 2.85$ & $28.35 \pm 1.18$ & 12 \\
\hline Atherinella brasiliensis & FURG 1191 & ESR & 8 & $10.45 \pm 1.11$ & $11.71 \pm 2.13$ & 12 \\
\hline Brevoortia pectinata & FURG 2274 & ESD & 8 & $11.67 \pm 1.03$ & $10.17 \pm 2.59$ & 12 \\
\hline Menticirrhus americanus & FURG 2048 & MARV & 24 & $70.18 \pm 1.28$ & $20.52 \pm 2.12$ & 12 \\
\hline Paralichthys orbignyanus & FURG 94020 & ESD & 24 & $520.13 \pm 2.89$ & $33.27 \pm 1.86$ & 12 \\
\hline Trichiurus lepturus & FURG 5013 & MARV & 29 & $223.89 \pm 2.10$ & $50.48 \pm 3.49$ & 12 \\
\hline Mugil curema & FURG 95147 & ESD & 34 & $980.10 \pm 3.51$ & $44.51 \pm 0.91$ & 12 \\
\hline
\end{tabular}


hyporegulated these ion levels at all other salinities (Figs. 1a and $1 \mathrm{~b}$ ); the isoionic line was crossed at approximately a salinity of 17. Plasma Ca ${ }^{2+}$ levels of G. barbus and M. furnieri were hyporegulated at salinities above 24 (Fig. 1c), but hyperregulated at lower salinities ( 0 and 5 ) with values near the isoionic line. Genidens barbus and M. furnieri also strongly hyporegulated $\mathrm{Mg}^{2+}$ levels, continuously keeping plasma levels below the isoionic line (Fig. 1d). Plasma $\mathrm{K}^{+}$ levels were hyperregulated in M. furnieri collected from water at salinities of $0,5,24$, and 26 , but they were hyporegulated at higher salt concentrations and crossed the isoionic line at approximately a salinity of 27 (Fig. 1e). In G. barbus plasma $\mathrm{K}^{+}$levels were hyperregulated at salinity 5 and hyporegulated at salinities 24 and 29.

\section{Discussion}

Classification by ecological guilds has previously been used to simplify information and allow for a better comparison of estuarine use between different systems (freshwater, estuarine and marine). In addition, this approach confirms the physiological and ionoregulatory mechanisms reported for fish found in estuarine regions (Elliott \& Dewailly, 1995; Prodócimo \& Freire, 2001; Garcia et al., 2003a, 2003b, 2004; Burns et al., 2006; Freire \& Prodócimo, 2007; Martinho et al., 2007; Da Rocha et al., 2009). Our findings also confirm results from earlier studies regarding the environments used by these fish species for feeding, reproduction and nursery grounds (Chao et al., 1985; Vieira \& Castello, 1996; Garcia et al., 2003a, 2003b, 2004; Burns et al., 2006).

The analysis of spatiotemporal distribution patterns of freshwater fish in the Patos Lagoon by Garcia et al. (2003b; 2004) and Vieira et al. (2010) showed that primary freshwater fish inhabiting the freshwater site (upper region of the Patos Lagoon) can be passively flushed into the estuarine zone during periods of high freshwater discharge and briefly remain in this zone. However, Garcia et al. (2003a) reported that when the estuarine zone returns to normal hydrological conditions primary freshwater fish that remain in the estuary may suffer from high physiological stress due to the intrusion of saline water into the estuary. In addition, only secondary freshwater fish, such as Cyprinodontiformes and Cichlidae, are able to remain in the estuary, and some euryhaline estuarine fish can move into freshwater sites of the Patos Lagoon during part of their life cycle (Chao et al., 1985; Vieira \& Castello, 1996; Barletta et al., 2010; Vieira et al., 2010).

The plasma ion levels of all fish species collected in our study (see Table 2) were similar to the values reported for other freshwater, estuarine and seawater teleosts (Chew \& Ip, 1990; Baldisserotto et al., 1990; Jensen et al., 1998; Prodócimo \& Freire, 2001; Borges et al., 2004; Becker et al., 2006; McDonald \& Grosell, 2006).

Table 2. Plasma ion levels of teleosts collected from water at different salinities from the São Gonçalo channel. Values in parentheses represent water ion levels. Values are presented as the means $\pm \operatorname{SEM}(n=12) ; r^{2}$ is related to the salinity $x$ plasma ion level relationship.

\begin{tabular}{|c|c|c|c|c|c|}
\hline \multirow[b]{2}{*}{ Species } & \multicolumn{5}{|c|}{$\left(\mathrm{mmol} \mathrm{L}^{-1}\right)$} \\
\hline & $\mathrm{Na}^{+}$ & $\mathrm{K}^{+}$ & $\mathrm{Cl}^{-}$ & $\mathrm{Ca}^{2+}$ & $\mathrm{Mg}^{2+}$ \\
\hline Salinity 0 & $(0.75 \pm 0.15)$ & $(0.08 \pm 0.01)$ & $(0.91 \pm 0.12)$ & $(1.16 \pm 0.04)$ & $(1.27 \pm 0.12)$ \\
\hline Cyphocharax voga & $223.38 \pm 3.90$ & $0.54 \pm 0.04$ & $129.36 \pm 0.84$ & $2.75 \pm 0.20$ & $1.06 \pm 0.11$ \\
\hline Hypostomus commersoni & $159.27 \pm 1.04$ & $6.07 \pm 0.14$ & $120.73 \pm 1.31$ & $3.03 \pm 0.15$ & $1.27 \pm 0.16$ \\
\hline Micropogonias furnieri & $217.22 \pm 2.70$ & $14.39 \pm 0.73$ & $126.43 \pm 3.31$ & $1.43 \pm 0.21$ & $0.70 \pm 0.06$ \\
\hline Parapimelodus nigribarbis & $198.73 \pm 2.33$ & $3.87 \pm 0.60$ & $142.61 \pm 3.67$ & $2.19 \pm 0.11$ & $1.33 \pm 0.21$ \\
\hline Pimelodus pintado & $180.33 \pm 2.24$ & $2.28 \pm 0.22$ & $168.45 \pm 2.99$ & $2.82 \pm 0.15$ & $1.54 \pm 0.22$ \\
\hline Rhamdia quelen & $165.28 \pm 2.05$ & $1.36 \pm 0.11$ & $112.63 \pm 2.51$ & $3.26 \pm 0.19$ & $2.17 \pm 0.17$ \\
\hline Salinity 5 & $(64.64 \pm 2.56)$ & $(2.04 \pm 0.15)$ & $(78.61 \pm 2.26)$ & $(2.37 \pm 0.22)$ & $(5.08 \pm 0.51)$ \\
\hline Cyphocharax voga & $197.64 \pm 2.03$ & $0.95 \pm 0.14$ & $133.63 \pm 4.42$ & $2.84 \pm 0.21$ & $1.67 \pm 0.28$ \\
\hline Genidens barbus & $228.02 \pm 1.65$ & $13.46 \pm 1.36$ & $161.92 \pm 1.62$ & $2.66 \pm 0.21$ & $0.89 \pm 0.20$ \\
\hline Micropogonias furnieri & $214.86 \pm 2.57$ & $12.72 \pm 1.62$ & $144.35 \pm 2.83$ & $2.44 \pm 0.14$ & $0.79 \pm 0.20$ \\
\hline Pimelodus pintado & $201.06 \pm 2.97$ & $0.54 \pm 0.04$ & $127.53 \pm 2.75$ & $2.97 \pm 0.21$ & $2.31 \pm 0.20$ \\
\hline Salinity 8 & $(105.33 \pm 3.12)$ & $(3.20 \pm 0.26)$ & $(125.77 \pm 3.05)$ & $(3.79 \pm 0.32)$ & $(8.13 \pm 0.35)$ \\
\hline Brevoortia pectinata & $200.58 \pm 1.49$ & $6.92 \pm 0.05$ & $161.79 \pm 4.00$ & $2.62 \pm 0.13$ & $2.27 \pm 0.09$ \\
\hline Salinity 24 & $(310.29 \pm 4.21)$ & $(9.81 \pm 0.35)$ & $(377.32 \pm 4.54)$ & $(11.36 \pm 0.84)$ & $(24.38 \pm 0.25)$ \\
\hline Genidens barbus & $233.08 \pm 4.07$ & $9.74 \pm 0.52$ & $196.45 \pm 2.73$ & $3.03 \pm 0.13$ & $1.34 \pm 0.09$ \\
\hline Menticirrhus americanus & $204.92 \pm 0.90$ & $2.77 \pm 0.04$ & $204.60 \pm 0.86$ & $3.44 \pm 0.20$ & $1.03 \pm 0.20$ \\
\hline Micropogonias furnieri & $225.47 \pm 2.97$ & $12.00 \pm 0.66$ & $166.50 \pm 0.92$ & $2.48 \pm 0.16$ & $0.91 \pm 0.23$ \\
\hline Paralichthys orbignyanus & $203.59 \pm 2.13$ & $3.69 \pm 0.32$ & $203.12 \pm 3.81$ & $2.71 \pm 0.16$ & $1.10 \pm 0.19$ \\
\hline Salinity 26 & $(336.15 \pm 4.31)$ & $(10.63 \pm 0.37)$ & $(408.76 \pm 6.31)$ & $(12.31 \pm 0.95)$ & $(26.42 \pm 0.28)$ \\
\hline Micropogonias furnieri & $234.73 \pm 2.63$ & $11.73 \pm 0.88$ & $174.64 \pm 0.73$ & $2.60 \pm 0.29$ & $0.95 \pm 0.27$ \\
\hline Salinity 29 & $(374.94 \pm 4.26)$ & $(11.86 \pm 0.26)$ & $(455.93 \pm 5.34)$ & $(13.73 \pm 0.89)$ & $(29.46 \pm 0.31)$ \\
\hline Genidens barbus & $247.23 \pm 4.14$ & $9.57 \pm 0.72$ & $214.68 \pm 2.74$ & $3.75 \pm 0.14$ & $1.92 \pm 0.19$ \\
\hline Micropogonias furnieri & $236.65 \pm 1.91$ & $9.94 \pm 0.56$ & $189.28 \pm 2.94$ & $2.67 \pm 0.13$ & $1.28 \pm 0.11$ \\
\hline Trichiurus lepturus & $236.65 \pm 2.24$ & $27.39 \pm 1.42$ & $136.21 \pm 3.28$ & $2.45 \pm 0.30$ & $2.11 \pm 0.28$ \\
\hline Salinity 34 & $(439.58 \pm 5.12)$ & $(13.90 \pm 0.29)$ & $(534.54 \pm 6.25)$ & $(16.10 \pm 1.06)$ & $(34.54 \pm 0.35)$ \\
\hline Micropogonias furnieri & $235.47 \pm 0.61$ & $6.75 \pm 0.40$ & $185.30 \pm 3.33$ & $2.85 \pm 0.11$ & $1.56 \pm 0.23$ \\
\hline Mugil curema & $225.47 \pm 0.65$ & $0.54 \pm 0.04$ & $150.57 \pm 0.78$ & $2.35 \pm 0.20$ & $0.98 \pm 0.20$ \\
\hline$r^{2}$ & 0.47 & 0.08 & 0.47 & 0.04 & 0.003 \\
\hline
\end{tabular}



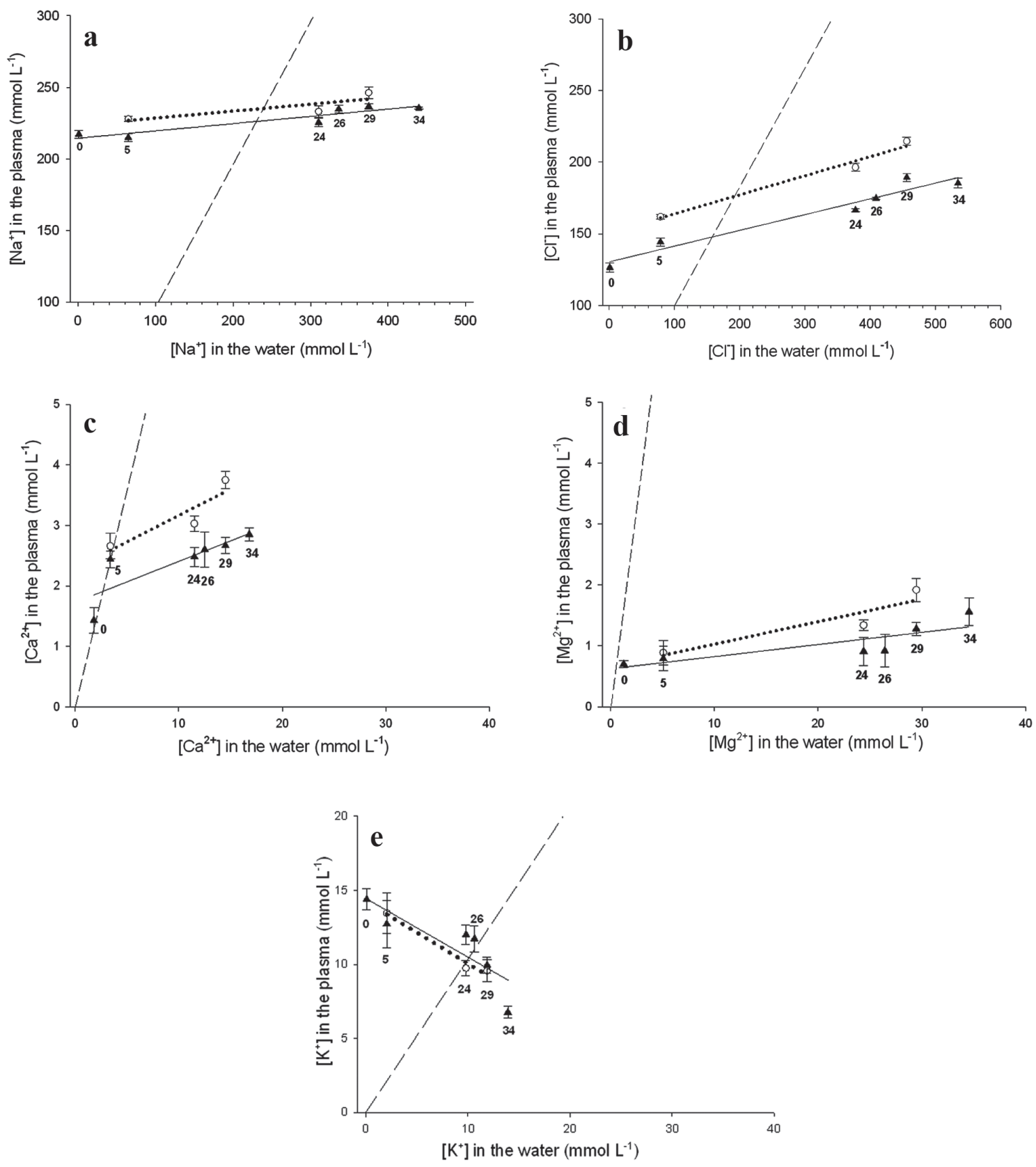

Fig. 1. Ion regulation curves for $\mathrm{Na}^{+}(\mathbf{a}), \mathrm{Cl}^{-}(\mathbf{b}), \mathrm{Ca}^{2+}(\mathbf{c}), \mathrm{Mg}^{2+}(\mathbf{d})$, and $\mathrm{K}^{+}(\mathbf{e})$ in the plasma of M. furnieri $(\mathbf{\Delta})$ and G. barbus $(\mathrm{O})$ collected from water at different salinities from the São Gonçalo channel. Data are expressed as the means $\pm \operatorname{SEM}(\mathrm{n}=12)(\mathrm{P}<$ 0.05); the traced line represents the isoionic line. The following equations were fitted to the data: Micropogonias furnieri $\left(\mathrm{Na}^{+}\right.$: $\mathrm{y}=214.52+0.051 \mathrm{x}, \mathrm{r}^{2}=0.87 ; \mathrm{Cl}: \mathrm{y}=130.45+0.110, \mathrm{r}^{2}=0.94 ; \mathrm{K}^{+}: \mathrm{y}=14.44-0.396 \mathrm{x}, \mathrm{r}^{2}=0.71 ; \mathrm{Ca}^{2+}: \mathrm{y}=1.73+0.067 \mathrm{x}, \mathrm{r}^{2}=0.70 ; \mathrm{Mg}^{2+}: \mathrm{y}=0.62+0.020 \mathrm{x}$, $\left.\mathrm{r}^{2}=0.70\right)$; Genidens barbus $\left(\mathrm{Na}^{+}: \mathrm{y}=223.74+0.048 \mathrm{x}, \mathrm{r}^{2}=0.70 ; \mathrm{Cl}: \mathrm{y}=150.56+0.133 \mathrm{x}, \mathrm{r}^{2}=0.98 ; \mathrm{K}^{+}: \mathrm{y}=14.23-0.419 \mathrm{x}, \mathrm{r}^{2}=0.97 ; \mathrm{Ca}^{2+}\right.$ : $\left.\mathrm{y}=2.29+0.087 \mathrm{x}, \mathrm{r}^{2}=0.82 ; \mathrm{Mg}^{2+}: \mathrm{y}=0.66+0.037 \mathrm{x}, \mathrm{r}^{2}=0.85\right)$, where $\mathrm{x}=$ salinity and $\mathrm{y}=$ plasma ion concentration $\left(\mathrm{mmol} \mathrm{L}^{-1}\right)$.

The capacity to adapt to different environmental salinities, i.e., to move between freshwater and seawater, is determined by the ability of fish to regulate ion uptake and excretion by the gills, gut and kidney and to maintain hydromineral balance (McCormick, 2001; Rodrígues et al., 2002; Martínez-Álvarez et al., 2005; McDonald \& Grosell, 2006).
In the present study, no relationship was observed between plasma ion levels and salinity when considering all collected species together. However, an individual analysis of each of the two species collected from water at three or more different salinities (M. furnieri and G. barbus) revealed a significant relationship between plasma ion levels and salinity. Previous 
studies reported a slight, but significant, positive linear relationship (over the salinity range tested) between plasma osmolality and ionic composition of the euryhaline flounder, Paralichthys orbignyanus, acclimated to different salinities (040) for 15 days (Sampaio \& Bianchini, 2002) and Pagrus auratus transferred from ambient seawater (salinity of 30 ) to either concentrated hyperosmotic (salinity 45) or diluted hyperosmotic (salinity of 15) environments for $168 \mathrm{~h}$ (Fielder et al., 2007).

All measured ions in the plasma of $M$. furnieri (at salinities of 29 and 34; except $\mathrm{Mg}^{2+}$ at a salinity of 29) and G. barbus (at a salinity of 29) were higher than those reported for both an estuarine fish, Sphoeroides testudineus, maintained in the laboratory at a salinity of 30 for 6 h (Prodócimo \& Freire, 2001) and a marine teleost, Opsanus beta, maintained in the laboratory at a salinity of 33 for 7 days (McDonald \& Grosell, 2006). These differences may be due to the fact that in our study blood was collected immediately after the fish were caught with a shrimp trawl deployed for $5 \mathrm{~min}$. Therefore, fish were subjected to a very stressful situation, and in stressed individuals there is an increase of blood flow to the gill and paracellular permeability (Cech et al., 1996; McDonald et al., 1991), which lead to dehydration and ion influx by diffusion because seawater is more concentrated than plasma (Gallaugher et al., 2001).

Both M. furnieri and G. barbus demonstrated a high capacity to regulate their plasma ion levels at low and high salinities. In marine/estuarine teleosts of different origin (Myoxocephalus octodecemspinosus, Acipenser naccarii, $P$. orbignyanus, $S$. testudineus, and $S$. greeleyi), plasma ion concentration is kept within narrow limits in diluted seawater or even in freshwater, indicating euryhalinity and a welldeveloped capacity of osmoionic regulation (Claiborne et al., 1994; Cataldi et al., 1995; Prodócimo \& Freire, 2001; Sampaio $\&$ Bianchini, 2002), as found in our study.

Plasma ion levels for M. furnieri and G. barbus were similar to those reported by Prodócimo \& Freire (2001) for pufferfish (S. testudineus and S. greeleyi), where $\mathrm{Na}^{+}$and $\mathrm{Cl}^{-}$were hyperregulated at low salinities but hyporegulated at high salinities, and $\mathrm{Mg}^{2+}$ was continuously and tightly hyporegulated. This hyporegulation of $\mathrm{Mg}^{2}$ is likely accomplished through renal tubular $\mathrm{Mg}^{2+}$ secretion, as observed by Beyenbach et al. (1993, 1997), Hentschel \& Zierold (1994) and Beyenbach (1995).

The inability of most freshwater fish species to enter hyperosmotic salinities may be caused by absence of hormonal, renal or intestinal control mechanisms (i.e., no neuroendocrine axis to stimulate oral ingestion) (Evans et al., 2005). Recent studies report that polyvalent cation receptors $(\mathrm{CaR})$ in the gill epithelium stimulate osmoregulatory changes by responding to changes in internal or external $\mathrm{Ca}^{2+}$ concentrations. Therefore, the osmoregulatory machinery controlled by these ion receptors could explain the capacity of both G. barbus and $M$. furnieri to hyporegulate plasma $\mathrm{Ca}^{2+}$ levels at higher salinities.

In summary, our data show that plasma ion levels were not directly related to water salinity when considering several species together (i.e., a general pattern could not be established). However, a relationship between plasma ion levels and salinity was observed when individually analyzing each species collected from a range of salinities, indicating that this pattern is species-specific. Moreover, similarities in the plasma ion regulatory capacity of both G. barbus and $M$. furnieri were observed at all salinity levels considered, allowing those fish to live in estuarine environments. Furthermore, these findings are completely consistent with the environmental distribution records of both species.

\section{Acknowledgements}

This study was supported by the CNPq (Conselho Nacional de Desenvolvimento Científico e Tecnológico) and funded by research fellowships from CAPES (Coordenação de Aperfeiçoamento de Pessoal de Nível Superior, Brazil) to A. G. Becker and J. F. Gonçalves and from the CNPq to B. Baldisserotto and J. P. Vieira.

\section{Literature Cited}

Altinok, I., S. M. Galli \& F. A. Chapman. 1998. Ionic and osmotic regulation capabilities of juvenile Gulf of Mexico sturgeon, Acipenser oxyrinchus de sotoi. Comparative Biochemistry and Physiology - Part A, 120: 609-616.

Baldisserotto, B. 2003. Osmoregulatory adaptations of freshwater teleosts. Pp. 179-201. In: Val, A. L. \& B. G. Kapoor (Eds.). Fish Adaptations. Enfield, Science Publishers, 418p.

Baldisserotto, B. \& O. M. Mimura. 1997. Ionic content of the gallbladder bile of the teleost fish Hoplias malabaricus in different digestive phases. Ciência \& Cultura, 49: 124-126.

Baldisserotto, B., O. M. Mimura \& L. C. Salomão. 1990. Gallbladder bile and plasma ionic content of some freshwater teleosts. Boletim de Fisiologia Animal, 14: 7-11.

Barletta, M., A. J. Jaureguizar, C. Baigun, N. F. Fontoura, A. A. Agostinho, V. M. F. Almeida-Val, A. L. Val, R. A. Torres, L. F. Jimenes-Segura, T. Giarrizzo, N. N. Fabré, V. S. Batista, C. Lasso, D. C. Taphorn, M. F. Costa, P. T. Chaves, J. P. Vieira \& M. F. M. Corrêa. 2010. Fish and aquatic habitat conservation in South America: a continental overview with emphasis on Neotropical systems. Journal of Fish Biology, 76: 2118-2176.

Becker, A. G., J. F. Gonçalves, L. O. Garcia, E. R. Behr, F. J. K. Mallmann, D. L. Graça \& B. Baldisserotto. 2006. Ion levels in the gastrointestinal tract content and plasma of four teleosts with different feeding habits. Fish Physiology and Biochemistry, 32: 105-112.

Becker, A. G., L. O. Garcia, D. Kochhann, J. F. Gonçalves, V. L. Loro \& B. Baldisserotto. 2009. Dissolved oxygen and ammonia levels in water that affect plasma ionic content and gallbladder bile in silver catfish. Ciência Rural, 39: 1768-1773.

Beyenbach, K. W. 1995. Secretory electrolyte transport in renal proximal tubules of fish. Pp. 85-105. In: Wood, C. M. \& T. J. Shuttleworth (Eds.). Cellular and Molecular Approaches to Fish Ionic Regulation. The Fish Physiology Series, vol. 14. San Diego, Academic Press, 352p.

Beyenbach, K. W., C. A. Freire, R. K. H. Kinne \& E. Kinne-Saffran. 1993. Epithelial transport of magnesium in the kidney of fish. Mineral and Electrolyte Metabolism, 19: 241-249.

Beyenbach, K. W., C. A. Freire, R. K. H. Kinne, E. Kinne-Saffran \& R. K. H. Kinne. 1997. Transport of magnesium across renal membrane vesicles: evidence for a channel? Pp. 443-450. In: 
Smetana, R. (Ed.). Advances in Magnesium Research. Magnesium in Cardiology, vol. 1, London, John Libbey, 600p.

Borges, A., L. V. Scotti, D. R. Siqueira, D. F. Jurinitz \& G. F. Wassermann. 2004. Hematologic and serum biochemical values for jundiá (Rhamdia quelen). Fish Physiology and Biochemistry, 30: 21-25.

Burns, M. D. M., A. M. Garcia, J. P. Vieira, M. A. Bemvenuti, D. M. L. Motta Marques \& V. Condini. 2006. Evidence of habitat fragmentation affecting fish movement between the Patos and Mirim coastal lagoons in southern Brazil. Neotropical Ichthyology, 4: 69-72.

Cataldi, E., E. Ciccotti, P. Di Marco, P. Bronzi \& S. Cataudella. 1995. Acclimation trials of juvenile Italian sturgeon to different salinities: morpho-physiological descriptors. Journal of Fish Biology, 47: 609-618.

Cech Jr J. J., S. D. Bartholow, P. S. Young \& T. E. Hopkins. 1996. Striped bass exercise and handling stress in freshwater: physiological responses to recovery environment. Transactions of American Fisheries Society, 125: 308-320.

Chao, L. H., L. E. Pereira \& J. P. Vieira. 1985. Estuarine fish community of the Patos Lagoon, Brazil. A baseline study. Pp. 429-450. In: Yanez-Arancibia, A. (Ed.). Fish Community Ecology in Estuaries and Coastal Lagoons: Towards and Ecosystem Integration. Mexico, DR (R) UNAM Press.

Chew, S. F. \& Y. K. Ip. 1990. Differences in the responses of two mudskippers, Boleophthalmus boddaerti and Periophthalmus chrysospilos to changes in salinity. Journal of Experimental Zoology, 256: 227-231.

Claiborne, J. B., J. S. Walton \& D. Compton-McCullough. 1994. Acid-base regulation, branchial transfers and renal output in a marine teleost fish (the long-hornet sculpin Myoxocephalus octodecimspinosus) during exposure to low salinities. Journal of Experimental Biology, 193: 79-95.

Da Rocha, A. M., D. P. Salomão de Freitas, M. Burns, J. P. Vieira, F. R. de la Torre \& J. M. Monserrat. 2009. Seasonal and organ variations in antioxidant capacity, detoxifying competence and oxidative damage in freshwater and estuarine fishes from Southern Brazil. Comparative Biochemistry and Physiology Part C, 150: 512-520.

Elliott, M. \& F. Dewailly. 1995. The structure and components of European estuarine fish assemblages. Netherlands Journal of Aquatic Ecology, 29: 397-417.

Evans, D. H., P. M. Piermarini \& K. P. Choe. 2005. The multifunctional fish gill: Dominant site of gas exchange, osmoregulation, acid-base regulation, and excretion of nitrogenous waste. Physiological Reviews, 85: 97-177.

Fielder, D. S., G. L. Allan, D. Pepperall \& P. M. Pankhurst. 2007. The effects of changes in salinity on osmoregulation and chloride cell morphology of juvenile Australian snapper, Pagrus auratus. Aquaculture, 272: 656-666.

Freire, C. A. \& V. Prodócimo. 2007. Special challenges to teleost fish osmoregulation in environmentally extreme or unstable habitats. Pp. 249-276. In: Baldisserotto, B., J. M. Mancera \& B. G. Kapoor (Eds.). Fish Osmoregulation. Enfield, Science Publishers.

Gallaugher, P. E., H. Thorarensen, A. Kiessling \& A. P. Farrell. 2001. Effects of high intensity exercise training on cardiovascular function, oxygen uptake, internal oxygen transport and osmotic balance in Chinook salmon (Oncorhynchus tshawytscha) during critical speed swimming. The Journal of Experimental Biology, 204: 2861-2872.

Garcia, A. M., J. P. Vieira \& K. O. Winemiller. 2003a. Effects of 1997-1998 El Niño on the dynamics of the shallow-water fish assemblage of the Patos Lagoon estuary (Brazil). Estuarine, Coastal and Shelf Science, 57: 489-500.

Garcia, A. M., M. B. Raseira, J. P. Vieira, K. O. Winemiller \& A. M. Grimm. 2003b. Spatiotemporal variation in shallow-water freshwater fish distribution and abundance in a large subtropical coastal lagoon. Environmental Biology of Fishes, 68: 215-228.

Garcia, A. M., J. P. Vieira, K. O. Winemiller \& A. M. Grimm. 2004. Comparison of the 1982-1983 and 1997-1998 El Niño effects on the shallow-water fish assemblage of the Patos Lagoon estuary (Brazil). Estuaries, 27: 905-914.

Hentschel, H. \& K. Zierold. 1994. Morphology and element distribution of magnesium-secreting epithelium: the proximal tubule segment PII of dogfish, Scyliorhinus caniculus (L.). European Journal of Cell Biology, 63: 32-42.

Martínez-Álvarez, R. M., A. Sanz, M. García-Gallego, A. Domezain, J. Domezain, R. Carmona, M. del Valle Ostos-Garrido \& A. E. Morales. 2005. Adaptive branchial mechanisms in the sturgeon Acipenser naccarii during acclimation to saltwater. Comparative Biochemistry and Physiology-Part A, 141: 183-190.

Martinho, F., R. Leitão, I. Viegas, M. Dolbeth, J. M. Neto, H. N. Cabral \& M. A. Pardal. 2007. The influence of an extreme drought event in the fish community of a southern Europe temperate estuary. Estuarine Coastal and Shelf Science, 75: 537-546.

McCormick, S. D. 2001. Endocrine control of osmoregulation in teleost fish. American Zoology, 41: 781-794.

McDonald, D. G., V. Cavdek \& R. Ellis. 1991. Gill design in freshwater fishes: interrelationships among gas exchange, ion regulation, and acid-base regulation. Physiological Zoology, 64:103-123.

McDonald, M. D. \& M. Grosell. 2006. Maintaining osmotic balance with an aglomerular kidney. Comparative Biochemistry and Physiology -Part A, 143: 447-458.

Prodócimo, V. \& C. A. Freire. 2001. Ionic regulation in aglomerular tropical estuarine pufferfishes submitted to seawater dilution. Journal of Experimental Marine Biology and Ecology, 262: 243-253.

Rodrígues, A., M. A. Gallardo, E. Gisbert, S. Santilari, A. Ibarz, J. Sánchez \& F. Castelló-Orvay. 2002. Osmoregulation in juvenile Siberian sturgeon (Acipenser baerii). Fish Physiology and Biochemistry, 26: 345-354.

Sampaio, L. A. \& A. Bianchini. 2002. Salinity effects on osmoregulation and growth of the euryhaline flounder Paralichthys orbignyanus. Journal of Experimental Marine Biology and Ecology, 269: 187-196.

Vieira, J. P. \& J. P. Castello. 1996. Fish fauna. Pp. 56-61. In: Seeliger, U., C. Odebrecht \& J. P. Castello (Eds.). Subtropical Convergence Marine Ecosystem. The Coast and the Sea in the Warm Temperate Southwestern Atlantic. Berlin, Springer Verlag, 306p.

Vieira, J. P., J. P. Castello \& L. E. Pereira. 1998. O ambiente e a biota do estuário da Lagoa dos Patos - ictiofauna. Pp. 60-67. In: Seeliger, U., C. Odebrecht \& J.P. Castello (Eds.). Os ecossistemas costeiro e marinho do extremo sul do Brasil. Ecoscientia, vol. 13, 337p.

Vieira, J. P., A. M. Garcia \& L. Moraes. 2010. A assembleia de peixes. Pp. 79-90. In: Seeliger, U. \& C. Odebrecht (Eds.). O Estuário da Lagoa dos Patos: Um século de transformações. 1 ed., Rio Grande: FURG, vol. 1, 180p.

Zall, D. M., M. D. Fisher \& Q. M. Garner. 1956. Photometric determination of chlorides in water. Analytical Chemistry, 28: 1665-1678.

Submitted January 11, 2011

Accepted August 21, 2011 Published December 26, 2011 